\title{
The Levels of Minerals and Vitamins in Some Wild and Cultured Mushroom Species from Turkey
}

\author{
Aydin Sukru Bengu ${ }^{1}$, Handan Çinar Yilmaz ${ }^{1}$, İbrahim Turkekul ${ }^{2}$ and Hakan Işik $^{3}$ \\ 1. Bingöl University, Vocational School of Health Services, Department of Medical Services and Techniques, Program of Medical \\ Laboratory Techniques, Bingöl 12000, Turkey \\ 2. Gaziosmanpaşa University, Faculty of Science, Biology Department, Tokat, Turkey \\ 3. Tokat Arts and Sciences Center, Tokat, Turkey
}

\begin{abstract}
In today's world, Pleurotus ostreatus (Jacq.) P. Kumm. and Agaricus bisporus (J. E. Lance) Imbach species which are grown both wild and cultured are very popular for humans diet because these species have been used in traditional medicine, economicaly and pharmacology. Two species of edible mushrooms Pleurotus ostreatus and Agaricus bisporus were selected from natural and cultured ones to determine vitamins and mineral contents levels. In this study, total protein levels, vitamin A-E and C levels and some mineral levels such as $\mathrm{Fe}, \mathrm{Cu}, \mathrm{Zn}, \mathrm{K}, \mathrm{Na}$ and $\mathrm{Ni}$ were investigated in both natural and cultured species.
\end{abstract}

Key words: Pleurotus ostreatus, Agaricus bisporus, minerals, vitamin, HPLC, AAS.

\section{Introduction}

Mushrooms contain high amounts of protein, vitamins, fiber, carbohydrates, fatty acids and minerals and also play an important role in the destruction of organic matter in the environment. Especially wild edible mushrooms have been used in many areas since ancient times, and popularity is increasing day by day. In today's world, Pleurotus ostreatus (Jacq.) P. Kumm. and Agaricus bisporus (J. E. Lange) Imbach species which are grown both wild and cultured are very popular for humans diet because these species have been used in traditional medicine, economically and pharmacology [1].

According to these popularities, in this study, total protein levels, vitamin $\mathrm{A}, \mathrm{E}$ and $\mathrm{C}$ levels and some mineral levels such as $\mathrm{Fe}, \mathrm{Cu}, \mathrm{Zn}, \mathrm{K}, \mathrm{Na}$, and $\mathrm{Ni}$ were investigated in both natural and cultured species to raise awareness and increase consumption. In this wise, these species can be used as human food

Corresponding author: Aydin Sukru Bengu, Assistant Professor, Determination of Vitamin and Mineral Contents at Natural and Cultured Pleurotus ostreatus and Agaricus bisporus, research fields: Vitamin, mineral, HPLC, AAS. supplement. In addition, while literature data which are done in Turkey only, give information about the wild species contents, but in this study, there is a comparison to wild and cultured samples to seeing differences of the measure of contents.

Iron $(\mathrm{Fe})$ is a trace element that is essential to humans and other living organisms. It functions as an integral part of hemoglobin, myoglobin, cytochrome, and other respiratory enzymes to bind with oxygen and facilitate its transport. Copper $(\mathrm{Cu})$ along with iron, is involved in the syntesis of hemoglobin. Copper functions in the formation of collagen and the maintenance of the myelin sheath surronding nerve fibers. Zinc (Zn) the formation of collagen is dependent on the trace element zinc. Zinc is also component of insülin, is involved in its storage and releases and apparently serves to increase the duration of insülin action after it is injected. Zinc is also involved in many processes such as DNA, RNA, protein synthesis and cell division, reproduction, night vision, immune system and healing of wounds. Nickel $(\mathrm{Ni})$, studies have shown nickel to be important for growth, reproduction, hematopoiesis, and iron and zinc 
metabolism. $\mathrm{Ni}$ is absorbed in the small intestine and excreted in urine. Sodium ( $\mathrm{Na}$ ) is the predominant cation of the extracellular fluid. Its majör function is that of maintaning the normal water distribution and osmotic pressure of plasma. Potassium (K) is the major intacellular cation of the body. It has an important role in cell metabolism by participating in regulation of many cellular process. $\mathrm{K}$ is also important in neuromuscular excitation. Vitamin A (retinol) designates a group of compounds essential for vision, cellular differantion, growth, reproduction, and immun system function. Naturally occuring compounds with vitamin A activity are retinol, retinal, and retinoic acid. Vitamin E ( $\alpha$-tocoferol) functions in the body as a powerful antioxidant; it is primary free radical scavenger in membranes. Vit $\mathrm{E}$ can prevent peroxidation of polyunsaturated fatty acids (PUFAs) in cell membranes. Vitamin C (ascorbic acid) functions as a potent agent and can donate one or two of its electrons to an acceptor molecule. A number of enzymes require Vit $\mathrm{C}$ for maximum activity. Vit $\mathrm{C}$ also functions as a reducing agent of antioxidant in nonenzymatic reactions [2].

\section{Materials and Methods}

These species were collected from Tokat's different localities and cultured. Total protein levels were studied with fume methods, vitamins were detected by reverse phase HPLC methods and the minerals were examined with microwave age burning after AAS. Study's natural samples were collected from Tokat's different localities. Mushroom samples cultivated in culture were obtained from Gaziosmanpaşa University Biology Department. Two species of edible mushrooms Pleurotus ostreatus and Agaricus bisporus were selected from natural and cultured ones to determine protein, vitamins and mineral contents levels. All analyses were carried out in the central research laboratory of Bingöl University.

\section{Results and Discussion}

According to the results, total protein levels were detected very close level at both species in cultured and natural ones (Figs. 1, 3-5).

While Vitamin A levels were found higher in cultured specimens and especially very high at Agaricus species samples, Vitamin C levels were found high at Pleurotus species samples (Tables 1 and 2). Besides these, Vitamin E was detected very high measured in Agaricus bisporus cultured samples $(1,590.16 \mu \mathrm{g} / \mathrm{g})$ also natural Pleurotus ostreatus samples had high level aganist the cultured samples (998.24 $\mu \mathrm{g} / \mathrm{g})$ (Figs. 2 and 3).

In addition, mineral contents of each sample to both

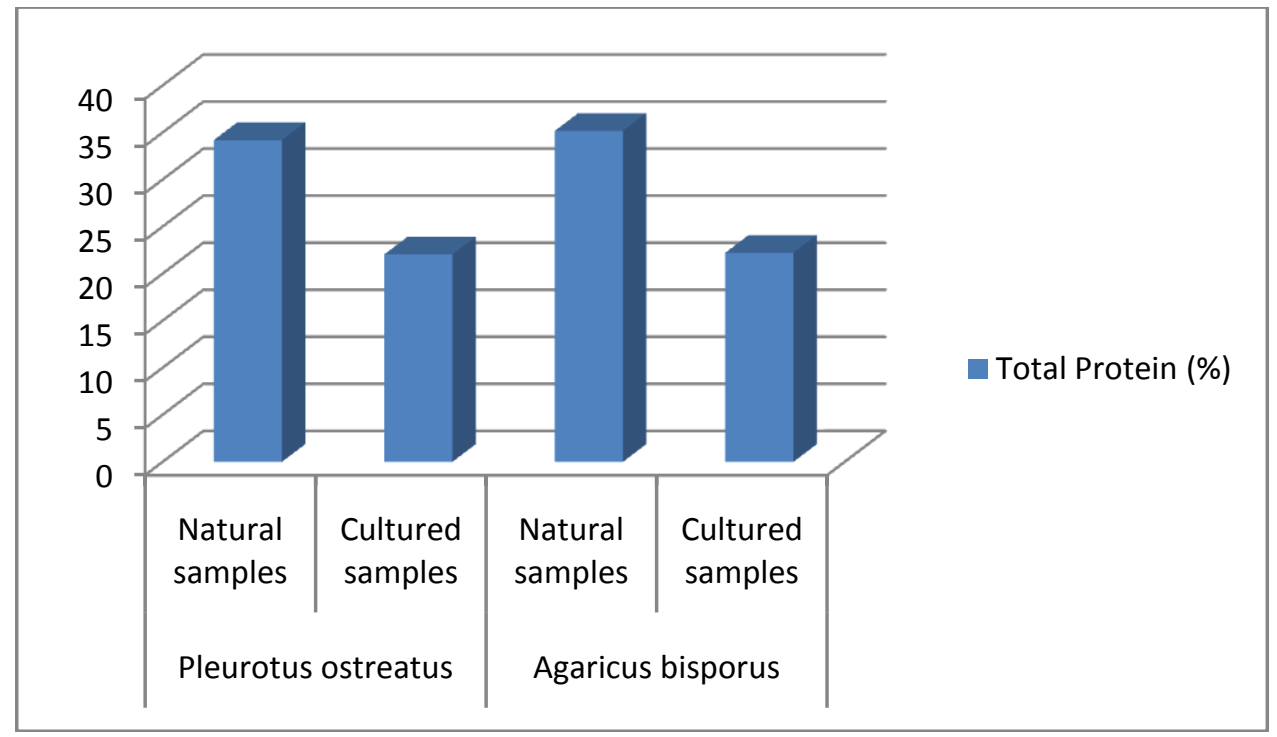

Fig. 1 Total protein levels of all mushroom samples (\%). 


\section{Mushroom Species from Turkey}

Table 1 The levels of Pleurotus ostreatus species contents.

\begin{tabular}{lllll}
\hline Pleurotus ostreatus & Total protein $(\%)$ & A Vitamin $(\mu \mathrm{g} / \mathrm{g})$ & E Vitamin $(\mu \mathrm{g} / \mathrm{g})$ & C Vitamin $(\mu \mathrm{g} / \mathrm{g})$ \\
\hline Natural samples & 36.25 & 9.62 & 998.24 & $1,481.25$ \\
Cultured samples & 23.18 & 66.86 & 654.16 & 334.36 \\
\hline
\end{tabular}

Table 2 The levels of Agaricus bisporus species contents.

\begin{tabular}{lllll}
\hline Agaricus bisporus & Total protein $(\%)$ & A Vitamin $(\mu \mathrm{g} / \mathrm{g})$ & E Vitamin $(\mu \mathrm{g} / \mathrm{g})$ & C Vitamin $(\mu \mathrm{g} / \mathrm{g})$ \\
\hline Natural samples & 34.80 & 106.14 & $1,020.81$ & 384.56 \\
Cultured samples & 23.74 & 159.20 & $1,590.16$ & 269.30 \\
\hline
\end{tabular}

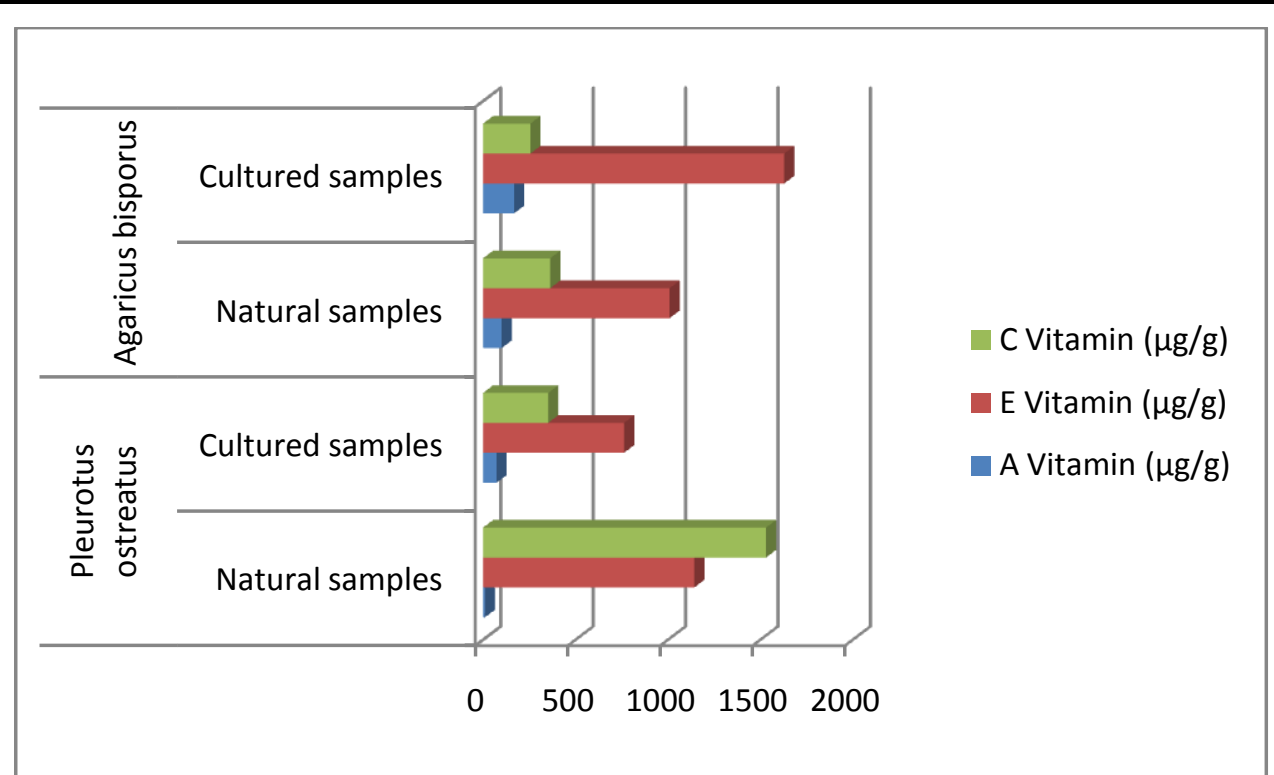

Fig. 2 The vitamin A-C and E levels of all mushroom samples $(\mu \mathrm{g} / \mathrm{g})$.

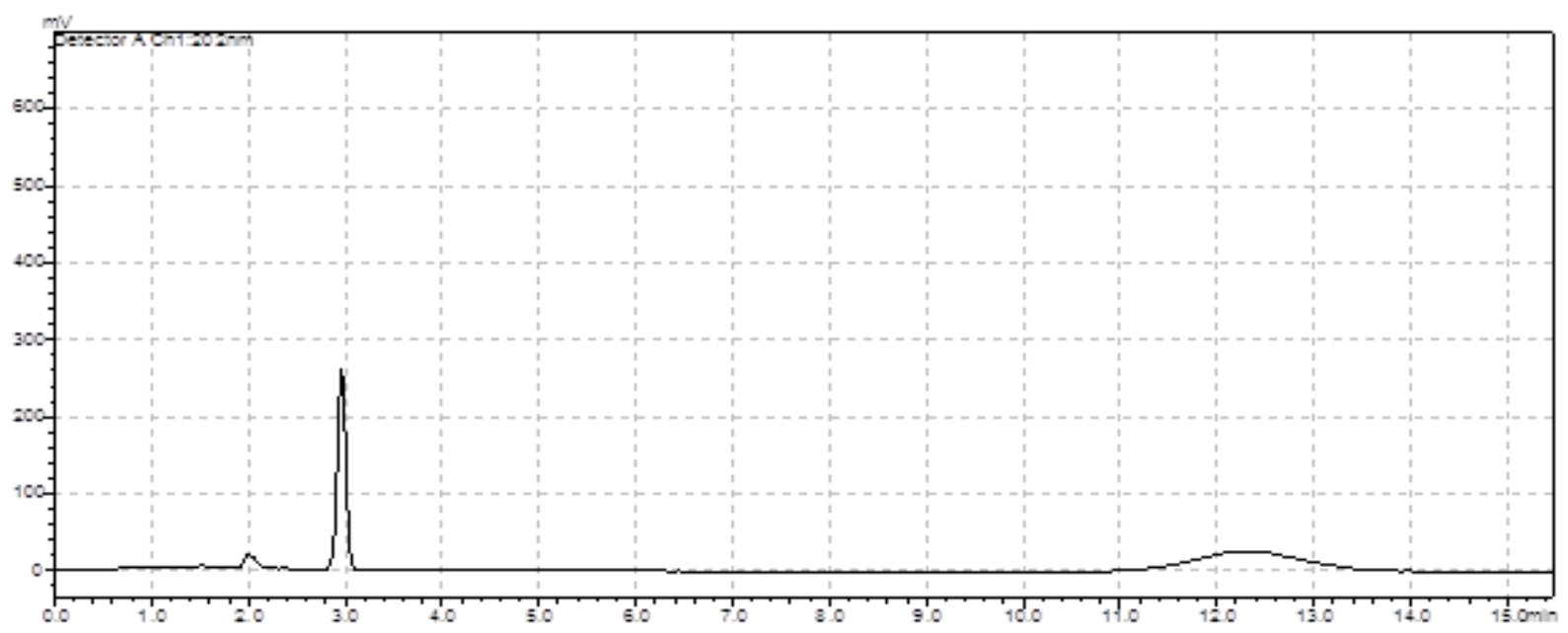

Fig. 3 The vitamin A chromatography at HPLC of mushroom species $(\mu \mathrm{g} / \mathrm{g})$.

species had different measure ranges. Fe mineral levels were found high in natural samples of both specimens but $\mathrm{Cu}, \mathrm{Zn}, \mathrm{K}$ and $\mathrm{Ni}$ leves were very high in natural Agaricus bisporus and Pleurotus ostreatus cultured samples. $\mathrm{Fe}, \mathrm{Zn}$ and $\mathrm{Ni}$ minerals were detected very close amounts among the cultured and natural samples for each species (Tables 3 and 4). In addition, for each mineral, it was found to be high in cultured samples of Pleurotus species, high in natural samples of Agaricus species. Pleurotus species has the 
higher quantity of $\mathrm{Cu}$ minerals than Agaricus species. In addition, cultured samples had the higher measure of $\mathrm{Cu}$ minerals than natural ones in Pleurotus species. $\mathrm{K}$ and $\mathrm{Na}$ minerals were measured at very high levels while Na minerals were seen very high in Pleurotus species, Agaricus species have not been measured.

Compared to some literature data which were done in Turkey's different region, our study results showed seen very high measures (Table 5).

According to the consequences, these mushroom species have high mineral contents and are very healthy for human natural life. So we can say, these mushroom samples can be used as human food supplement.

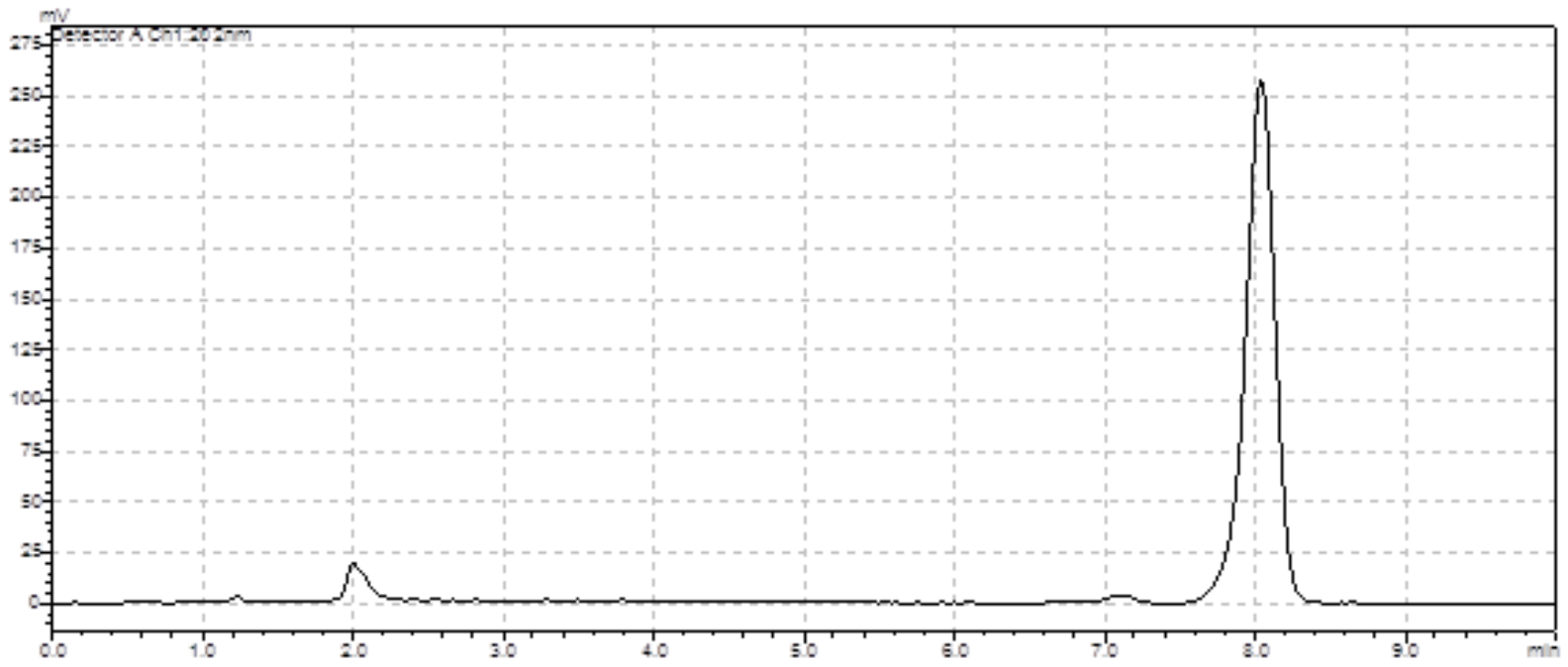

Fig. 4 The vitamin C chromatography at HPLC of mushroom specis $(\mu \mathrm{g} / \mathrm{g})$.

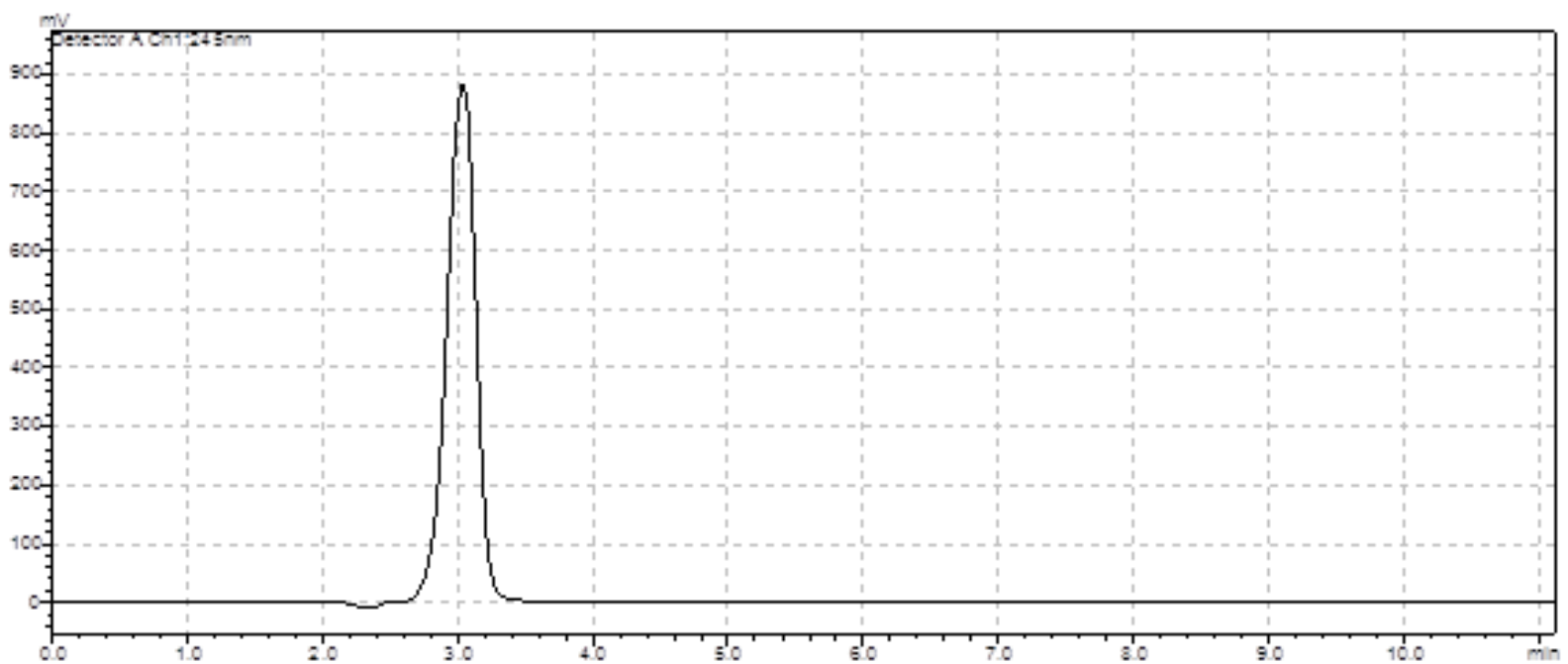

Fig. 5 The vitamin E chromatography at HPLC of mushroom species $(\mu \mathrm{g} / \mathrm{g})$.

Table 3 The levels of mineral contents of Pleurotus ostreatus species.

\begin{tabular}{lllllll}
\hline Pleurotus ostreatus & $\mathrm{Fe}(\mathrm{mg} / \mathrm{kg})$ & $\mathrm{Cu}(\mathrm{mg} / \mathrm{kg})$ & $\mathrm{Zn}(\mathrm{mg} / \mathrm{kg})$ & $\mathrm{Ni}(\mathrm{mg} / \mathrm{kg})$ & $\mathrm{K}(\mathrm{g} / \mathrm{kg})$ & $\mathrm{Na}(\mathrm{g} / \mathrm{kg})$ \\
\hline Natural samples & 593.20 & 872.00 & 339.60 & 0.094 & 69.32 & 47.96 \\
Cultured samples & 286.80 & $4,632.00$ & 345.20 & 0.100 & 76.88 & 195.80 \\
\hline
\end{tabular}


The Levels of Minerals and Vitamins in Some Wild and Cultured

Mushroom Species from Turkey

Table 4 The levels of mineral contents of Agaricus bisporus species.

\begin{tabular}{lllllll}
\hline Agaricus bisporus & $\mathrm{Fe}(\mathrm{mg} / \mathrm{kg})$ & $\mathrm{Cu}(\mathrm{mg} / \mathrm{kg})$ & $\mathrm{Zn}(\mathrm{mg} / \mathrm{kg})$ & $\mathrm{Ni}(\mathrm{mg} / \mathrm{kg})$ & $\mathrm{K}(\mathrm{g} / \mathrm{kg})$ & $\mathrm{Na}(\mathrm{g} / \mathrm{kg})$ \\
\hline Natural samples & 797.20 & 205.20 & 524.80 & 0.132 & 125.92 & - \\
Cultured samples & 743.60 & 138.80 & 405.60 & 0.118 & 11.56 & - \\
\hline
\end{tabular}

Table 5 The literature data for about the species mineral contents $(P$. ostreatus a, b means that: they were collected from different areas of district).

\begin{tabular}{|c|c|c|c|c|c|c|c|}
\hline Some literature & Mushroom species & $\mathrm{Fe}(\mathrm{mg} / \mathrm{kg})$ & $\mathrm{Cu}(\mathrm{mg} / \mathrm{kg})$ & $\mathrm{Zn}(\mathrm{mg} / \mathrm{kg})$ & $\mathrm{Ni}(\mathrm{mg} / \mathrm{kg})$ & $\mathrm{K}(\mathrm{g} / \mathrm{kg})$ & $\mathrm{Na}(\mathrm{g} / \mathrm{kg})$ \\
\hline \multirow{2}{*}{ Demirbaş 2001 [3] } & Pleurotus ostreatus & 86.1 & 13.6 & 29.8 & - & - & - \\
\hline & Agaricus bisporus & 126 & 5.22 & 17.8 & - & - & - \\
\hline \multirow{3}{*}{ Uzun et al. 2011 [4] } & Pleurotus ostreatus a & 125 & 54 & 250 & 2.51 & 8,270 & - \\
\hline & Pleurotus ostreatus $b$ & 65 & 62 & 265 & 2.64 & 17,775 & - \\
\hline & Agaricus bisporus & 50 & 78 & 110 & 1.10 & 27,490 & - \\
\hline Dursun et al. 2006 [5] & Pleurotus ostreatus & 507.3 & 14.3 & 58.3 & 3.7 & $21,603.3$ & - \\
\hline Gençcelep et al. 2009 [6] & Pleurotus ostreatus & 682 & 47.1 & 142 & - & 21.9 & 1.53 \\
\hline Iş̧1dak et al. 2007 [7] & Agaricus bisporus & 0.23406 & 0.04182 & 0.03858 & 0.00424 & - & - \\
\hline
\end{tabular}

\section{References}

[1] Sesli, E., and Tüzen, M. 1999. "Level of Trace Elements in The Fruiting Bodies of Macrofungi Growing in The East Black Sea Region of Turkey." Food Chemistry 65: 453-60.

[2] Anerson, S. C., and Susan, C. 2007. Clinical Chemistry. Long Grove, Illionis: Waveland Press.

[3] Demirbaş, A. 2001. "Concentrations of 21 Metals in 18 Species of Mushrooms Growing in the East Black Sea Region." Food Chemistry 75: 453-7.

[4] Uzun, Y., Gençcelep, H., Kaya, A., and Akçay, M. E. 2011. "The Mineral Contents of Some Wild Edible
Mushrooms." Ekoloji 20: 80: 6-12.

[5] Dursun, N., Özcan, M. M., Kaşık, G., and Öztürk C. 2006. "Mineral Contents of 34 Species of Edible Mushrooms Growing Wild in Turkey." Journal of The Science of Food and Agriculture 86: 1087-94.

[6] Gençcelep, H., Uzun, Y., Tunçtürk, Y., and ve Demirel, K. 2009. "Determination of Mineral Contents of Wild-Growing Edible Mushrooms." Food Chemistry 113: 1033-6.

[7] Işıldak, Ö., Türkekul, İ., Elmastaş, M., and Aboul-Enein, H. Y. 2007. "Bioaccumulation of Heavy Metals in Some Wild-Grown Edible Mushrooms." Analytics Letters 40: 1099-116. 